\title{
DEFINITION OF MOTHER IN THE ENGLISH LEGAL SYSTEM ${ }^{1}$
}

\author{
OSCAR CELADOR ANGÓN*
}

\begin{abstract}
The purpose of this paper is to analyse how the term "mother" is defined in the English legal system. This question has recently been raised in English courts due to the McConnel case; where a woman, who had undergone a gender transition and acquired full legal recognition as a male, gave birth to a child and asked to be registered as the father of his child. In the first part of the paper, I will study the legal frame and the main decisions of the English courts. In the second part, I will analyse the decisions of the European Court of Human Rights and the consequences of the McConnel case in English family law. And finally, I will explain the role that the principle of the best interests of the child plays in this context.
\end{abstract}

Keywords: transsexual, transgender, best interests of the child, right to respect for private and family life.

Summary: 1. Introduction. 2. Legal frame. 2.1. The Gender Recognition Act. 2.2. The Births and Deaths Registration Act. 2.3. Human Fertilisation and Embryology Acts. 2.4. The Equality Act. 2.5. The Children Act. 3. Judicial precedents. 4. The European Court of Human Rights case law. 5. The McConnel case. 6. Conclusions.

\section{INTRODUCTION}

The term mother has traditionally been defined as "female parent", creating a link between the sex of the parent and motherhood. Consequently, the mother is defined as the person with the ability to become pregnant and give birth from a biological point of view (Margaria and Freeman, 2012). This definition is merely terminological, since the parents' obligations towards their children are the same, regardless of their sex or sexual identity (Peral, 2000).

Biological advances, and the parallel development of law, have allowed a person born as female, and who subsequently undergoes a specific procedure to legally change their sex to male, to give birth (Moyal and Shelley, 2010). Should that person to be registered as their child's "mother" or "father"? If the person is registered as the mother, the legal system would be recognizing that a male can be a mother. However, in the case that the person is registered as the father, the legal system would allow a person born female to be legally father. The interests of all the parties involved are clear. The person giving birth wants to name himself according to his outward appearance or his sexual identity. The person born wants to know who is the person who gave birth to him. And

\footnotetext{
* Universidad Carlos III de Madrid, Spain (Oscar.celador@uc3m.es)

1 "New challenges of the Law' Project. This work has been supported by the Madrid Government (Comunidad de Madrid-Spain) under the Multiannual Agreement with UC3M in the line of Excellence of University Professors (EPUC3M06), and in the context of the V PRICIT (Regional Programme of Research and Technological Innovation)"
} 
finally, the State has a special interest in registering properly the identity of the new born and the parents for purposes of civil affiliation (Besson, 2007).

This question has been answered by the High Court of Justice in the case R v The Registrar General of England and Wales ${ }^{2}$. This case is known as the McConnel case, despite the fact that the general rule in this type of cases is to name the plaintiff or defendant with a letter of the alphabet. However, because Mr. McConnel publicized the process and the court's decision in the media, the name of the plaintiff is public and the court removed the cloak of confidentiality from the claimant (Pocklington, 2019).

The purpose of this paper is to analyse how the term "mother" is defined in the English legal system. In the first part of this paper, I will study the English legal frame and the main decisions of the English courts. In the second part, I will analyse the decisions of the European Court of Human Rights in this context. And finally, I will explain the consequences of the McConnel case in English family law.

Finally, it is important to take in account that this research is limited exclusively to the English law, since in the United Kingdom four legal subsystems coexist (English, Welsh, Scottish and Northern Irish). The subsystems have common elements and are under the jurisdiction of the Supreme Court of the United Kingdom, but they have relevant differences in the field of marriage and family law.

\section{Legal FRAME}

The English legal system provides for a gender change procedure very similar to the Spanish sex change procedure. The main difference between both models is that in the English model more relevance is given to personal experience and identity; but formally the English model provides for gender change and the Spanish provides for sex change (Agius and Tobler, 2014; Celador, 2020; Cowan, 2005; Salazar Benítez, 2015; Vidal, 2003).

In this part of our research, we are going to analyse the main laws that affect the free development of the personality of people who change their gender. It is necessary to take into account that the Gender Recognition Act is the main law designed to regulate the procedure and the consequences of gender change in English law. However, to properly understand the legal framework, we will also analyse the English law related to birth registration (Births and Deaths Registration Act), children's rights (The Children Act), assisted reproductive techniques (Human Fertilization and Embryology Acts) and equality and non-discrimination based on sex, gender or sexual orientation (The Equality Act).

Once the legal regulation has been studied, we will focus our research in how the English courts have interpreted this regulation in specific cases.

\footnotetext{
${ }^{2} \mathrm{R}$ (on the application of TT) -v- The Registrar General for England and Wales and others, [2019] EWHC 2384 (Fam).
} 


\subsection{The Gender Recognition Act}

The Gender Recognition Act of 2004 (GRA) is the key piece in the regulation of the legal status of transgender people. Applicants of either gender who are aged at least 18 may request a gender recognition certificate to the gender recognition panel, if they meet the following requirements: "(a) has or has had gender dysphoria, (b) has lived in the acquired gender throughout the period of two years ending with the date on which the application is made, (c) intends to continue to live in the acquired gender until death" 3 . The procedure does not provide the possibility of a change of opinion for the applicants, as far as they have to intend to continue living in the acquired gender until death; and it does not require a surgical operation or a medical treatment as a condition to obtain the gender recognition certificate (Grabham, 2010; Sandland, 2005; Sharpe, 2007; Whittle, 2006).

Regarding the evidences, applications must include "(a) a report made by a registered medical practitioner practising in the field of gender dysphoria and a report made by another registered medical practitioner (who may, but need not, practise in that field), or (b) a report made by a [registered psychologist] practising in that field and a report made by a registered medical practitioner (who may, but need not, practise in that field)" $"$.

If the applicant is married or has a civil partner, since marriage of same-sex couples is legal in England (Fishbayn, 2007) ${ }^{5}$, it is necessary for the applicant's partner to declare whether they intend to continue to be married after the change of gender ${ }^{6}$. Due to the fact that the matrimonial consent continues, since the applicant's partner expressly declares it, the marriage bond continues (Taitz, 1986).

The main consequence of the gender recognition certificate is that: "the person's gender becomes for all purposes the acquired gender (so that, if the acquired gender is the male gender, the person's sex becomes that of a man and, if it is the female gender, the person's sex becomes that of a woman)" ". Parenthood is regulated in the GRA as follows: "The fact that a person's gender has become the acquired gender under this Act does not affect the status of the person as the father or mother of a child"8. According to this regulation, it is necessary to differentiate between the acts performed before and after obtaining the gender recognition certificate. In theory, a person who was born female but who has acquired full legal recognition as male would be the mother of his children born before the recognition certificate; and a person who was born male but who has acquired full legal recognition as female would be the father of her children born before

\footnotetext{
${ }^{3}$ Sections 1-2 of the Gender Recognition Act of 2004.

${ }^{4}$ Section 3 of the Gender Recognition Act of 2004.

${ }^{5}$ Same-sex marriage was legalised in England, Wales, and Scotland in 2014; and in Northern Ireland in January 2020. Vid. Marriage (Same Sex Couples) Act 2013 (c. 30).

${ }^{6}$ Section 3 of the Gender Recognition Act of 2004.

${ }^{7}$ Section 9 of the Gender Recognition Act of 2004.

${ }^{8}$ Section 12 of the Gender Recognition Act of 2004.
} 
the recognition certificate. This interpretation allows to accommodate the legal gender to the gender identity; as well as to differentiate between the gender identity, the biological gender and the legal gender in the family law context.

The gender recognition certificate may affect social security benefits for the applicants and their spouses or civil partners. Gender recognition certificate applicants should notify to Her Majesty's Revenue and Customs (HMRC) upon issue the certificate, so HMRC will update their National Insurance and tax records with details of the acquired gender.

The European Court of Justice held in the case IMB v Secretary of State for Work and Pensions, that the Council Directive 79/7/EEC of 19 December 1978 (on the progressive implementation of the principle of equal treatment for men and women in matters of social security): "must be interpreted as precluding national legislation which requires a person who has changed gender not only to fulfil physical, social and psychological criteria but also to satisfy the condition of not being married to a person of the gender that he or she has acquired as a result of that change, in order to be able to claim a State retirement pension as from the statutory pensionable age applicable to persons of his or her acquired gender" 10 . The Court established that the UK requirement for transgendered persons violated EU law, because they had to be unmarried to a person of the gender that he or she has acquired as a result of that change, in order to be able to claim a State retirement pension according with the age required to persons of his or her acquired gender.

According to the Court, "therefore, it must be held that the national legislation at issue in the main proceedings accords less favourable treatment, directly based on sex, to a person who changed gender after marrying, than that accorded to a person who has kept his or her birth gender and is married, even though those persons are in comparable situations" $"$.

The GRA protects the right to privacy of transgender people, establishing that it is an offence for a person who has acquired protected information in an official capacity to disclose the information to any other person ${ }^{12}$. This provision especially affects to the employers and to the local or public authorities.

Finally, the Registrar General Office must have a Gender Recognition Register, with the following purposes: "(a) make an entry in the Gender Recognition Register containing such particulars as may be prescribed in relation to the person's birth and any other prescribed matter, (b) secure that the UK birth register entry is marked in such manner as may be prescribed, and (c) make traceable the connection between the entry

\footnotetext{
${ }^{9}$ Case C-451/16, Judgment of the Court (Grand Chamber) of 26 June 2018

${ }^{10}$ Paragraph 54.

11 Paragraph 54.

${ }^{12}$ Section 22 of the Gender Recognition Act of 2004.
} 
in the Gender Recognition Register and the UK birth register entry"13. The link between the Gender Recognition Register and the UK birth register entry allows to offer neutral information on the gender of birth of the transgender and the acquired gender; but the complete certificate can violate the transgender right to privacy, in the event that the transgender wants to keep the gender change secret ${ }^{14}$.

\subsection{The Births and Deaths Registration Act}

The birth of every child born in England shall be registered by the Registrar of births and deaths according with the Births and Deaths Registration Act of 1953 (BDRA). This regulation is supported by the right of individuals to know the identity of the person responsible for their birth as accurately as possible (Appell, 2014; McCandless, 2017).

The Registrar has to require information concerning birth, with the purpose: "to give information to the best of that person's knowledge and belief of the particulars required to be registered concerning the birth" 15 . The Registrar can provide two types of birth certificate: the full version, which also contains the parents' details; or a short version, which contains only the newborn details. The short certificate of birth can be obtained by any person as the BDRA establishes that: "(1) Any person shall, on furnishing the prescribed particulars, be entitled to obtain from the Registrar General, a superintendent registrar or a registrar a short certificate of the birth of any person. (2) Any such certificate shall be in the prescribed form and shall be compiled in the prescribed manner from the records and registers in the custody of the Registrar General [...] Provided that any particulars prescribed in addition to name, surname, sex and date of birth shall not include any particulars relating to parentage or adoption contained in any such records or registers" 16 .

The father and mother of a child have to deliver the information concerning birth to the Registrar within forty-two days. The mother and the father are defined in relation to an adopted child as "the child's natural mother" or the "child's natural father" 17.

In adoption cases, the Registrar General is required to maintain an adopted children Register, from which there is a traceable (but not publicly open) link to the adopted child's original birth certificate. The link is openly marked with a side-note indicating "adopted". Certificates for the child are produced from the adopted children Register, again in the same form as a long-form birth certificate, and recording those adopting as "parent(s)" The long certificate does not identify the child's biological mother or father, nor is there any publicly available link to the original birth certificate which does; and the short form certificate has the same form as any other short form birth certificate, so it doesn't reflect that the child has been adopted.

\footnotetext{
${ }^{13}$ Schedule 3 Registration, Part 1, of the Gender Recognition Act of 2004.

${ }^{14}$ Schedule 3 Registration, Part 1, of the Gender Recognition Act of 2004.

${ }^{15}$ Section 4 of the Births and Deaths Registration Act of 1953

${ }^{16}$ Section 33 of the Births and Deaths Registration Act of 1953

${ }^{17}$ Section 41 of the Births and Deaths Registration Act of 1953

${ }^{18}$ Sections 77-79 of the Adoption and Children Act of 2002.
} 
The BDRA neither provide a specific definition of mother, only in the case of adopted children is it specified that the mother is the biological mother. Consequently, it is possible to differentiate between the adoptive mother and the biological mother, or between the mother for legal purposes and the biological mother.

\subsection{Human Fertilisation and Embryology Acts}

The Human Fertilisation and Embryology Acts of 1990 and 2008 (HFEA) differentiate between motherhood as a biological and as a legal reality. The HFEA establishes rights and obligations in the cases of fertility treatments with respect to donors of biological material, and in the cases of surrogacy and adoption. However, this regulation does not provide a specific solution for cases of gender change (Alghrani, 2009; Fox, 2009; McCandless and Sheldon, 2010).

The HFEA defines the term mother as "(1) The woman who is carrying or has carried a child as a result of the placing in her of an embryo or of sperm and eggs, and no other woman, is to be treated as the mother of the child. (2) Subsection (1) does not apply to any child to the extent that the child is treated by virtue of adoption as not being the woman's child. (3) Subsection (1) applies whether the woman was in the United Kingdom or elsewhere at the time of the placing in her of the embryo or the sperm and eggs" 19 . According to this definition, only women can be mothers; so what happens to those women who change their gender? should that person to be registered as their child's mother or father?

Another important aspect to keep in mind is that, at least theoretically, only women can receive an embryo, sperm and eggs, in the context of the HFEA. The treatment services are defined in the HFEA as: "medical, surgical or obstetric services provided to the public or a section of the public for the purpose of assisting women to carry children". The nonmedical fertility services are defined in the HFEA as: "any services that are provided, in the course of a business, for the purpose of assisting women to carry children, but are not medical, surgical or obstetric services" ${ }^{20}$. Therefore, those women who change their gender and subsequently want to enjoy the fertility treatments may have their request denied, because they are legally considered male once they got the gender recognition certificate, as far as they become for all purposes the acquired gender ${ }^{21}$.

The father is defined in the HFEA according with his relation with the mother. In the case of a woman married (or civil partner) to a man at time of treatment: "If (a) at the time of the placing in her of the embryo or of the sperm and eggs or of her artificial insemination, $\mathrm{W}$ was a party to a marriage [with a man] [or a civil partnership with a man], and (b) the creation of the embryo carried by her was not brought about with the sperm of the other party to the marriage [or civil partnership], then, subject to section 38(2) to (4),

\footnotetext{
${ }^{19}$ Section 33 of the Human Fertilisation and Embryology Act of 2008.

${ }^{20}$ Section 2 of the Human Fertilisation and Embryology Act of 1990.

${ }^{21}$ Section 9 of the Gender Recognition Act of 2004.
} 
the other party to the marriage [or civil partnership] is to be treated as the father of the child unless it is shown that he did not consent to the placing in her of the embryo or the sperm and eggs or to her artificial insemination (as the case may be)"'22.

In those cases, in which a woman is the other parent it is necessary to differentiate between different scenarios. These are some examples. First, a woman in civil partnership or marriage to a woman at time of treatment is to be treated as the parent of the child, "unless it is shown that she did not consent to the placing in W of the embryo or the sperm and eggs or to her artificial insemination". Second, a treatment provided to a woman who agrees that a second woman to be the parent. Or third, when an embryo is transferred after the death of a female spouse, civil partner or intended parent who did not provide sperm; in this case, if no one else "is to be treated (i)as the father of the child by virtue of section 35 or 36 or by virtue of section 45(2) or (3), or (ii)as a parent of the child by virtue of section 42 or 43 or by virtue of adoption, then the other woman is to be treated for the purpose mentioned in subsection (4) as a parent of the child"23.

The use of the terms parent and father are incompatible respect the same chid, as "where a woman is treated by virtue of section 42 or 43 as a parent of the child, no man is to be treated as the father of the child" 24 . Therefore, according with the HFEA, children can have a mother and a father or a mother and a parent, but the term father is used exclusively for males and the term parent is used for females.

\subsection{The Equality Act}

Gender reassignment is one of the characteristics protected by the Equality Act of 2010 (EA) (Davies et al., 2016; Fell and Dyban, 2017; Hand, 2012). The EA establishes that: "(1) A person has the protected characteristic of gender reassignment if the person is proposing to undergo, is undergoing or has undergone a process (or part of a process) for the purpose of reassigning the person's sex by changing physiological or other attributes of sex. (2) A reference to a transsexual person is a reference to a person who has the protected characteristic of gender reassignment. (3) In relation to the protected characteristic of gender reassignment - (a) a reference to a person who has a particular protected characteristic is a reference to a transsexual person; (b) a reference to persons who share a protected characteristic is a reference to transsexual person" 25 .

Regarding direct discrimination, "a person (A) discriminates against another (B) if, because of a protected characteristic, A treats B less favourably than A treats or would treat others"; and "If the protected characteristic is sex [...] (b) in a case where B is a man, no account is to be taken of special treatment afforded to a woman in connection with pregnancy or childbirth" 26 . Combined discrimination is also protected in cases of gender

\footnotetext{
${ }^{22}$ Section 35 of the Human Fertilisation and Embryology Act of 2008.

${ }^{23}$ Sections 42-47 of the Human Fertilisation and Embryology Act of 2008.

${ }^{24}$ Section 45 of the Human Fertilisation and Embryology Act of 2008.

${ }^{25}$ Section 7 of the Equality Act of 2010.

${ }^{26}$ Section 13 of the Equality Act of 2010.
} 
reassignment; in concrete: "A person (A) discriminates against another (B) if, because of a combination of two relevant protected characteristics, A treats B less favourably than A treats or would treat a person who does not share either of those characteristics. (2) The relevant protected characteristics are: (a) age; (b) disability; (c) gender reassignment; (d) race (e) religion or belief; (f) sex; (g) sexual orientation. (3) For the purposes of establishing a contravention of this Act by virtue of subsection (1), B need not show that A's treatment of B is direct discrimination because of each of the characteristics in the combination (taken separately). (4) But B cannot establish a contravention of this Act by virtue of subsection (1) if, in reliance on another provision of this Act or any other enactment, A shows that A's treatment of B is not direct discrimination because of either or both of the characteristics in the combination [... $]^{\prime 27}$.

According to the Equality Act of 2010, in theory it would be discriminatory for an assisted reproduction clinic to refuse a woman to be treat after gender reassignment. A possible solution to this problem could be to interpret that those people with the ability to give birth, regardless of their gender or sex, can be users of fertility treatments in the context of the HFEA.

\subsection{The Children Act}

It is important to take in account the regulation about parental responsibility contained in the Children Act of 1989 (CA), as "where a child's father and mother were married to [, or civil partners of, ] each other at the time of his birth, they shall each have parental responsibility for the child", but "where a child: (a) has a parent by virtue of section 42 of the Human Fertilisation and Embryology Act 2008; or (b) has a parent by virtue of section 43 of that Act and is a person to whom section 1(3) of the Family Law Reform Act 1987 applies, the child's mother and the other parent shall each have parental responsibility for the child" 28 .

In the case that the child's father and mother were not married or civil partners each other at the time of his birth: "(a) the mother shall have parental responsibility for the child; (b) the father shall have parental responsibility for the child if he has acquired it (and has not ceased to have it)] in accordance with the provisions of this Act". And "Where a child has a parent by virtue of section 43 of the Human Fertilisation and Embryology Act 2008 and is not a person to whom section 1(3) of the Family Law Reform Act 1987 applies: (a) the mother shall have parental responsibility for the child; (b) the other parent shall have parental responsibility for the child if she has acquired it (and has not ceased to have it) in accordance with the provisions of this Act" ${ }^{\prime 2}$.

The CA creates different regimes based on two principles: the existence of a civil relationship between parents (married couple or civil partners), and the pre-eminence

\footnotetext{
${ }^{27}$ Section 14 of the Equality Act of 2010.

${ }^{28}$ Section 2 of the Children Act of 1989.

${ }^{29}$ Section 2 of the Children Act of 1989.
} 
of the mother's position in the context of filiation. In the case that a female who has subsequently undergone gender transition and acquired full legal recognition as male was consider the father of the child, he would have to apply for parental responsibility due to the fact that, according with the CA, only the mother has automatic parental responsibility for the child. In order to acquire parental responsibility as the father, the CA establish that: "he and the child's mother make an agreement (a "parental responsibility agreement") providing for him to have parental responsibility for the child" 30 . It seems clear that the CA does not foresee the possibility of a man giving birth, as far as if the transgender male is considered the father, who is the mother?

In summary, the English legal system has not foreseen what happens in those cases in which a male transgender has the capacity to give birth, in order to attribute specific legal consequences to that situation.

\section{JUDICIAL PRECEDENTS}

Until the McConnel case, the English courts have only ruled on one occasion on a matter directly related to the maternity/paternity of a person which has undergone under gender transition. The claimant was a transgender woman (male to female transsexual) who requested to be registered as the parent of his children -as it is a neutral term- or, in the event that his previous request wasn't attended, as parent/father ${ }^{31}$. This is a very relevant decision, since, as we will see later, it was used as an important reference by the High Court of Justice in the McConnel case.

The claimant was born male, he was married to a woman (KK), and had two children. In the birth certificate of both children the claimant was identified as the father. Before her second child was born, the claimant felt the desire to live as a woman, and was diagnosed with gender identity disorder and concomitant gender dysphoria. She changed her name to a female forename, and formally renounced to use her former title "Mr" in favour of "Mrs", and from that date she has lived as a woman. She started a feminising hormone treatment, which was on-going when the court ruled on her request, as the treatment pathway requires two years living as a female before consideration is given for referral for gender reassignment surgery.

As previously noted, the English legal system doesn't require the gender reassignment surgery in order to acquired full legal recognition of the new gender identity according with the GRA $^{32}$. Consequently, the claimant had obtained a gender recognition certificate, which recognized her gender identity as female.

According to her gender identity, the claimant requested to the local registrar that the birth registration of her oldest son could be re-registered, with the new registration

\footnotetext{
${ }^{30}$ Section 4 of the Children Act of 1989.

${ }^{31} \mathrm{R}(\mathrm{JK}) \mathrm{v}$ The Registrar General (The Secretary of State for the Home Department and others intervening) [2015] EWHC 990 (Admin); [2016] 1 All ER 354.

${ }^{32}$ Sections 1-2 of the Gender Recognition Act of 2004.
} 
showing the claimant's new name of JK, and with her identified as "parent" rather than as "father"; or, if that were not possible, as "father/parent". The registrar couldn't address the claimant request that her former name of $\mathrm{CK}$ was entered on the certificate as her previous name, and completed the form showing KK as "mother" and the Claimant, in her name $\mathrm{JK}$, as "father" 33 .

The claimant appealed the registry decision because, in her opinion, the requirement to show her as "father" on the birth certificate of each of her children was a breach of the right to respect for private life under article 8 of the European Convention on Human Rights (ECHR). The claimant also denounced that she was discriminated on the basis of her transgender characteristic under article 14 of the ECHR.

The court highlighted the absence of regulation and judicial decisions in this field, both in the case law of the European Court of Human Rights and in most of the legal systems of European countries. Portugal is the only European country that has regulated specifically this situation, permitting a child's birth certificate to be amended, but only if the child is over 18 years of age and consents ${ }^{34}$.

The court didn't consider that in requiring a man who changes gender to female to be listed as "father" on the full birth certificate of a child -of whom she is the biological father-, to be in breach of article 8 or 14 of the ECHR. Regarding the breach of Article 8 of the ECHR, the court established that: "i) Whilst gender is an important element of an individual's fundamental identity, in practice, after a father had changed gender, the statutory scheme contains a number of checks and balances (such as section 22 of the GRA 2004); the room for disclosure of the fact of the individual's gender change by requiring her to be shown as "father" on her children's birth certificates is limited; and the interference with her article 8 rights will be small. ii) The interference with the article 8 rights of the relevant children will also be small; and will be counterbalanced, at least to an extent, by the fact that, if their birth certificates were altered to show their father as "parent" (or, if it were possible, "father/parent") that itself would interfere with the child's article 8 right to have his or her fundamental identity recognised. In some cases, such alteration may be adverse to the best interests of the relevant children" 35 .

The birth registration scheme is based on the principle that "a birth certificate shows the relevant details of a child as at his or her birth, and those details cannot be changed". This system has been designed to protect the rights and interests of parents, children, and the public interest of collecting all the information related to the birth.

The court either found a breach of article 14 of the ECHR, since "I consider that this case falls within the ambit of article 8, and I accept that transsexualism is a notion or characteristic covered by article 14 as falling within "other status" [...] This is a case in

\footnotetext{
${ }^{33}$ Paragraph 11.

34 Paragraph 117.

${ }^{35}$ Paragraph 123.
} 
which, in the event, the article 14 claim does not add anything of substance to the article 8 claim. Discrimination under article 14 is, in my judgment, justified for the same reasons as those set out above in relation to article $8 " 36$.

\section{The European Court of Human Rights case law}

The United Kingdom has transposed the European Convention into its internal legislation through the Human Rights Act of 1998 (HRA). The HRA guarantees the right to respect for private and family life, establishing that " 1 . Everyone has the right to respect for his private and family life, his home and his correspondence. 2. There shall be no interference by a public authority with the exercise of this right except such as is in accordance with the law and is necessary in a democratic society in the interests of national security, public safety or the economic well-being of the country, for the prevention of disorder or crime, for the protection of health or morals, or for the protection of the rights and freedoms of others" ${ }^{\prime 37}$. It should also be noticed that the regulation of the United Kingdom has been repeatedly denounced before the European Court of Human Rights (ECHR), so its compatibility with the Convention has been directly tested (Falletti, 2014; GonzalezSalzberg, 2014; Hart, 2016; Korkiamäki, 2014; Sanz, 2003, 2014; Ziegler, 2020).

In Rees $\mathrm{v}$ The United Kingdom ${ }^{38}$ a female to male transsexual complained that United Kingdom did not allow his birth registration to be modified according with his physical appearance as male, after having undergone a sex change surgery financed by the public health system. The government argued that "in the absence of any error or omission at the time of birth, the making of an alteration to the register as to the sex of the individual would constitute a falsification of the facts contained therein and would be misleading to other persons with a legitimate interest in being informed of the true situation. They contended that the demands of the public interest weighed strongly against any such alteration"39.

The ECHR held that there had been no violation of the right to respect for private and family life, as the British regulation was intended to guarantee the legitimate interest of offering truthful information about the register of births. The court recognized that the position of the British authorities fit within the margin of appreciation that the Convention recognizes to States, and that the changes demanded by the applicant "would have important administrative consequences and would impose new duties on the rest of the population" 40 .

Regarding the right to marry and to found a family, in Cossey $\mathrm{v}$ The United Kingdom ${ }^{41}$ the court held that: "although some contracting States would now regard as

\footnotetext{
${ }^{36}$ Paragraphs 126-127.

${ }^{37}$ Schedule 1, Art. 8 of the Human Rights Act of 1998.

${ }^{38}$ Case of Rees v The United Kingdom (Application n ${ }^{\circ}$ 9532/81), 1986.

${ }^{39}$ Paragraph 42.

40 Paragraph 43.

${ }^{41}$ Case of Cossey v The United Kingdom (Application n 10843/84), 1990.
} 
valid a marriage between a person in Miss Cossey's situation and a man, the developments which have occurred to date (see paragraph 40 above) cannot be said to evidence any general abandonment of the traditional concept of marriage. In these circumstances, the Court does not consider that it is open to it to take a new approach to the interpretation of Article 12 (art. 12) on the point at issue. It finds, furthermore, that attachment to the traditional concept of marriage provides sufficient reason for the continued adoption of biological criteria for determining a person's sex for the purposes of marriage, this being a matter encompassed within the power of the contracting States to regulate by national law the exercise of the right to marry" ${ }^{\prime 2}$.

A similar claim was presented under the ECHR in $\mathrm{X}, \mathrm{Y}$ and $\mathrm{Z} v$ The United Kingdom $^{43}$. In this case a female to male transsexual, living in a permanent and stable union with a woman, who gave birth as a result of artificial insemination by a donor, claim that the British law did not allow him to have a legal relationship with his partner, nor with his partner's son. The court maintained its referenced position in the Cossey and Rees cases, and held that there has been no violation of the European Convention.

The court decision in Goodwin $\mathrm{v}$ the United Kingdom ${ }^{44}$ is a landmark case regarding the recognition of gender identity and the legal status of transsexuals. Mrs. Goodwin (a male to female transsexual) claimed that she had problems and faced sexual harassment at work due to her gender reassignment. According with the social security regulation, she was treated as a man; which meant that she had to contribute up to 65 years, while women only contributed at that time until the age of 60 , so she had chosen to pay her contributions herself to avoid conflicts with her employers. Despite having changed her gender, Mrs. Goodwin's social insurance situation didn't change, therefore her employers could know that she had previously worked as a male, with the resulting embarrassment and humiliation. And finally, she complained about her inability to marry.

The court found that the United Kingdom violated Mrs. Goodwin's rights to respect for her private and family life and her right to marry. The court created a new case law line to those legal systems, such as the case of the United Kingdom, that choose to recognize the right to change of sex. According with the court, those legal systems must be consistent with that decision and remove the obstacles that prevent individuals from fully integrating into society, and legally acting according to their sex identity. As a consequence of this decision United Kingdom passed the GRA ${ }^{45}$.

The modification of the court's case law was justified in "the importance of keeping the need for appropriate legal measures under review having regard to scientific and societal developments" 46 . The Court emphasised that "the Court finds that the respondent

\footnotetext{
42 Paragraph 42.

${ }^{43}$ Case of X, Y and Z v The United Kingdom (Application $\left.n^{\circ} 21830 / 93\right), 1997$.

${ }^{44}$ Case of Goodwin v The United Kingdom (Application $n^{\circ}$ 28957/95), 2002.

${ }^{45}$ Section 9 of the Gender Recognition Act of 2004.

${ }^{46}$ Paragraph 93.
} 
Government can no longer claim that the matter falls within their margin of appreciation, save as regards the appropriate means of achieving recognition of the right protected under the Convention. Since there are no significant factors of public interest to weigh against the interest of this individual applicant in obtaining legal recognition of her gender reassignment, it reaches the conclusion that the fair balance that is inherent in the Convention now tilts decisively in favour of the applicant. There has, accordingly, been a failure to respect her right to private life in breach of Article 8 of the Convention" ${ }^{47}$.

The right to marriage was also debated by the court, concluding that "while it is for the contracting State to determine inter alia the conditions under which a person claiming legal recognition as a transsexual establishes that gender reassignment has been properly effected or under which past marriages cease to be valid and the formalities applicable to future marriages (including, for example, the information to be furnished to intended spouses), the Court finds no justification for barring the transsexual from enjoying the right to marry under any circumstances" $" 48$. In other words, States can decide whether to legally recognize gender re-assignment; but if they choose to recognize gender reassignment, individuals must be able to exercise all rights according to their gender identity, including the right to marry and to found a family.

Regarding the rights of transgender children, the ECHR has not taken any specific decision. However, the court has analyzed the right of children to know the identity of their biological parents, which is very interesting for this research, since the modification of the sex or gender of the parents may have consequences on the information shown by their children's birth certificate.

In the following lines, we are going to study two decisions of the ECHR that were used as a reference to decide the McConnel case.

In Godelli v Italy ${ }^{49}$ the court analyzed the Italian legal system, which allows the identity of the parents to be kept secret in certain cases, which may collide with the children's right to respect for her private and family life. According with the Italian Civil Code, "one of the parents may decide not to recognize his or her child. In order to exercise that right, the mother must, at the time of the birth, request the hospital to keep her identity secret. In such a case a medical file containing medical information about the mother and child is drawn up. Only the child's general practitioner may have access to the file, with the permission of the child's guardian" ${ }^{50}$. Ms Godelli was abandoned by her mother at birth, and her birth certificate records indicated, regarding the identity of her mother, that "a woman, who did not consent to being named, gave birth to a baby girl", making it impossible for the applicant to exercise her right to identity, which includes knowing the identity of her parents if possible.

\footnotetext{
${ }^{47}$ Paragraph 93.

${ }^{48}$ Paragraph 103.

${ }^{49}$ Godelli v Italia (Application n $\left.{ }^{0} 33783 / 09\right), 2012$.

${ }^{50}$ Paragraph 16.
} 
The Italian government justified its position in the existence of a conflict between two private interests, and the margin of appreciation that States should enjoy in this area. The court connected the right to identity with the knowledge of the identity of the parents, as the Court established that: "the right to an identity, which includes the right to know one's parentage, is an integral part of the notion of private life. In such cases, particularly rigorous scrutiny is called for when weighing up the competing interests. The Court must examine whether a fair balance has been struck in the present case between the competing interests: on the one hand, the applicant's right to have access to information about her origins and, on the other, the mother's right to remain anonymous" ${ }^{\prime}$.

The court held that the Italian law violated article 8 of the European Convention, because "Italian law does not allow a child who was not formally recognised at birth and was subsequently adopted to request either access to non-identifying information concerning his or her origins or the disclosure of the mother's identity. Accordingly, the Court considers that the Italian authorities failed to strike a balance and achieve proportionality between the interests at stake and thus overstepped the margin of appreciation which it must be afforded" 52 . The court highlighted the absence of mechanisms that would harmonize the interests of the parties (the mother and her daughter), as well as the absolute protection of the mother's right, even completely sacrificing the interests of the children.

In Mennesson v France and Labassee v France ${ }^{53}$ the court maintained its position regarding the recognition of filial relations. France didn't recognize the legal parent-child relationship established by two married couples with their children thorough surrogacy agreements in the United States, as the French authorities maintained that the surrogacy agreements entered into by Mr and Mrs Mennesson and Mr and Mrs Labassee were unlawful.

The construction made by the court of the parental affiliate relations is very interesting, as one of the parents was also the child's biological father. In the Court's view: "the right to identity was an integral part of the concept of private life and there was a direct link between the private life of children born following surrogacy treatment and the legal determination of their parentage [...] given the importance of biological parentage as a component of each individual's identity, it could not be said to be in the best interests of the child to deprive him or her of a legal tie of this nature when the biological reality of that tie was established and the child and the parent concerned sought its full recognition. Not only had the tie between the twins and their biological father not been acknowledged when the request was made for the birth certificates to be entered in the register; in addition, the recognition of that tie by means of a declaration of paternity or adoption, or on the basis of de facto enjoyment of status, would fall foul of the prohibition established by the case-law of the Court of Cassation in that regard. In thus preventing the recognition and establishment of the children's legal relationship with their biological father, the French State had overstepped the permissible margin of appreciation". In accordance with this approach, the Court held that the children's right to respect for their private life were violated.

\footnotetext{
${ }^{51}$ Paragraphs 52-53.

52 Paragraph 58.

${ }^{53}$ Mennesson v France (Application n ${ }^{\circ}$ 65192/11), 2014. Labassee v France (Application n ${ }^{\circ}$ 65941/11), 2014.
} 


\section{The McConnel CaSe}

In the McConnel case the court was required to define the term "mother" under the law of England and Wales ${ }^{54}$. This case is quite relevant since until then no court has previously been required to legally define what mother means.

This is a unique case, because the term mother has traditionally been associated with those women who give birth. According with this logic, not all women are mothers, but in order to be a mother it is necessary to be a woman. Freddy McConnell was born female, later he followed the gender transition procedure and became legally recognised as male, his passport and National Health Service records were amended to show his gender as male. Under medical guidance, he suspended testosterone treatment and later commenced fertility treatment in England at a clinic, whose records show that Mr. McConnell was registered as ' $\mathrm{M}$ ' for male. Finally, he conceived, carried and gave birth to a child.

When Mr. McConnell tried to register the birth of his son in the registry office, he was informed that he would have to be registered as the child's "mother", regardless that he was registered with his current male name. Mr McConnell request to be registered as "father" or, if this option was not available, as the "parent". Due to the refusal of the registry office to comply with his request, Mr McConnell brought a claim in judicial review, claiming a breach of his rights under the European Convention.

Before starting the analysis of the judicial decision, it is important to note that the plaintiff is considered a male for all purposes, because, according with the GRA, "where a full gender recognition certificate is issued to a person, the person's gender becomes for all purposes the acquired gender (so that, if the acquired gender is the male gender, the person's sex becomes that of a man and, if it is the female gender, the person's sex becomes that of a woman)" ${ }^{\prime 5}$. Consequently, the court had to answer two questions: how should a man who give birth to a child be registered in the civil registry? And is that man the "mother" or the "father" of his child?

The court emphasized that at the same period that Mr McConnell declared to the gender recognition panel that he intended to continue to live as a male until his death, he suspended the programme of testosterone therapy in order to get pregnant by artificial insemination. Mr McConnell justified his position under the panel, in the fact that he wasn't questioned about this situation during the application process and he had not volunteered the information ${ }^{56}$.

Due to the absence of any statutory definition of "mother", the Court look for a definition at common law, establishing that: "prior to the mid-20th century, when conception and pregnancy other than through sexual intercourse was unknown and where gender was primarily determined by genital examination at birth and then maintained for life. In that

\footnotetext{
${ }^{54} \mathrm{R}$ (on the application of TT) -v- The Registrar General for England and Wales and others, [2019] EWHC 2384 (Fam).

${ }^{55}$ Section 9 (1) of the Gender Recognition Act of 2004.

${ }^{56}$ Paragraph 44.
} 
context, the lack of copious authority on the question does not, given the nature of the issue, indicate that there is any doubt as to the answer. In those times, at common law a person who became pregnant, through the insemination of an egg in their womb, and who subsequently gave birth to a child must have been that child's mother. In this the law was doing no more than reflecting common sense, common experience and the basic facts of life; motherhood was established by the act of giving birth, or 'parturition' to use Lord Simon's phrase, and a person who became pregnant and gave birth was a 'mother' $[. .$.$] In that regard,$ being a 'mother' is to describe a person's role in the biological process of conception, pregnancy and birth; no matter what else a mother may do, this role is surely at the essence of what a 'mother' undertakes with respect to a child to whom they give birth. It is a matter of the role taken in the biological process, rather the person's particular sex or gender" 57 .

According with the common law, the person who carries a pregnancy and gives birth to a child is that child's mother. The term mother is defined by the biological connection between two human beings, depending on the role that both of them play in the process of pregnancy and birth. Thus, the main question that had to answer the court is whether the provisions of the GRA modify the common law position in those cases where the person who conceives, carries and gives birth to a child is, at the time of birth, male ${ }^{58}$.

The court analyzed the main regulation in this area (The Gender Recognition Act, the Births and Deaths Registration Act, the Human Fertilization and Embryology Acts and the Equality Act and the Children Act), concluding that none of them modifies the common law principle which defines the mother as the person who undergoes process of carrying a pregnancy and giving birth, regardless of his/her gender.

In order to answer all the questions raised, the court also focused on the analysis of the rights protected by the European Convention, and specifically the right to respect for private and family life (Article 8) and the prohibition of discrimination (Article 14).

The court noticed that the ECHR had not yet ruled on the specific issue that arises in this case. The Government accepted that the requirement for a trans-man, to be named as "mother" on the child's birth certificate, interferes with both the claimant's and the child's Art 8 rights ${ }^{59}$. In consequence, the relevant questions that have to be answered are, on the one hand, if the State had a legitimate interest to limit the mentioned rights; and, on the other hand, if there were other solutions available to guarantee the right to respect for private and family life ${ }^{60}$.

According with the court, in order to define the "best interests" of a child in the related circumstances: "a balance must be struck between the parent's individual right to privacy and the child's right to know about their biological identity" ${ }^{61}$. The right to know the biological identity is linked with other rights such as the right of donors of material for

\footnotetext{
${ }^{57}$ Paragraphs 133,139.

${ }^{58}$ Paragraph 136.

${ }^{59}$ Paragraph 191.

${ }^{60}$ Paragraph 244.

${ }^{61}$ Paragraph 194.
} 
fertility treatments to have their identity kept secret, or with the legislation of some States that guarantees the anonymity of the identity of parents in certain circumstances (Clark, 2012; Turkmendag, 2012, 58).

The court focused on the decisions of the ECHR in Mennesson v France and Godelli $\mathrm{v}$ Italy, and established that the interference with the Art 8 rights was justified as being in accordance with the law, for a legitimate purpose, proportionate and fair. The court established that: "the aim of the UK birth registration scheme, as the Government argue is the case, in requiring the identity of the person who gave birth to a child to be recorded as such is, therefore, entirely legitimate and of a high order of importance in the context of social policy. It is of note that in almost all the countries within the Council of Europe a trans-man who gives birth will be registered as the 'mother' $[\ldots]$ the degree of interference in their Art 8 rights is substantial, I also accept the Government case (in line with the judgment of Hickinbottom $\mathrm{J}$ in JK) that the number of occasions when a full birth certificate may be produced and TT's status as YY's mother, and therefore the fact that he is trans-gender, would be disclosed, will be small. The adverse impact upon TT, significant though it will be were it to occur, is very substantially outweighed by the interests of third parties and society at large in the operation of a coherent registration scheme which reliably and consistently records the person who gives birth on every occasion as mother" 62 .

Another aspect that the court also valued was the effect of registration in the rights to third parties. The recognition of the right to a trans-parent to register a birth in their acquired gender may violate third parties' rights, and especially the rights of the child and the trans-parent's partner. The right to identity includes being able to know who is the person responsible for the birth, and that person traditionally has been known as the mother. In the event that McConnell was registered as the father, his son would be denied the right to know who is responsible of his birth, and he would be discriminated respect to those children whose parents are not transgender, because his mother's name would not be registered. Likewise, the registration of a person according to their acquired gender violate the right to respect for private and family life to their partner/spouse.

Finally, the court's position can be summarized as follows: "there is a material difference between a person's gender and their status as a parent. Being a 'mother', whilst hitherto always associated with being female, is the status afforded to a person who undergoes the physical and biological process of carrying a pregnancy and giving birth. It is now medically and legally possible for an individual, whose gender is recognised in law as male, to become pregnant and give birth to their child. Whilst that person's gender is 'male', their parental status, which derives from their biological role in giving birth, is that of "mother" 63 . Therefore, the terms father and mother are not connected to the person's gender. The gender of the person isn't relevant, but his/her role in the process of conception, pregnancy and birth of a child. Gender is a dynamic concept that can evolve with the identity of the person, while the terms father and mother are static concepts that are not modified by the acquisition of gender under the GRA.

\footnotetext{
${ }^{62}$ Paragraphs 266, 272.

${ }^{63}$ Paragraph 279.
} 


\section{Conclusions}

The recognition of rights to transgender people has been constant in the 21st century, among other reasons thanks to the influence of the decision of the European Court of Human Rights in Goodwin v the United Kingdom. The English model is an exceptional example of the legal evolution carried out by most of the European States, so that people who change their sex or gender can freely develop their personality and especially in the context of personal relationships and family law.

The general rule has traditionally been to recognize to people who change sex or gender the rights recognized to the acquired sex or gender, so that the equality is absolute and any type of discrimination is avoided. The recognition of the same-sex marriage and the social and political activism of the LGBT movements has been very supportive in this context, since it has made possible to sensitize both society and politicians about the need to facilitate the free development of the personality of individuals regardless of their sex, gender or sexual orientation.

English law does not specifically define the term mother, because traditionally the term mother has been associated exclusively with the female sex, and until the McConnel case there have been no relevant lawsuits or legal conflicts in this context. The GRA has developed a model in which, on the one hand, it is not required a surgical operation or a medical treatment as a condition to obtain the gender recognition certificate; and on the other hand, the person's gender becomes for all purposes the acquired gender. The BDRA is supported by the right of individuals to know the identity of the person responsible for their birth as accurately as possible, and that person is named mother (in the case of the biological mother) or adoptive mother. But the BDRA does not define the term mother either. The HFEA differentiates between motherhood as a biological and as a legal reality, but it does not provide a specific solution for cases of gender change; as far as clarifies that the use of the terms parent and father/mother are incompatible regarding the same child.

One of the main gaps in English law in this context is that, according with the GRA, gender change requires applicants to declare their intention to continue to live in the acquired gender until death. Therefore, the procedure does not foresee any solution for those cases in which the applicants, once they have changed their gender, change their opinion.

The European Court of Human Rights has developed a case law line to those legal systems, such as the case of the United Kingdom, that choose to recognize the right of individuals to change of sex/gender. The court has established that those countries must remove the obstacles that prevent individuals from fully integrating into society, and legally acting according to their sex/gender identity. However, the European Court has not defined the term mother, nor what are the obligations of the States in this context.

Regarding the rights of children, the European Court has established that children have the right to know the identity of their biological parents, as an integral part of their right to respect for private and family life, guaranteed by Article 8 of the European Convention. 
The discussion opened in the McConnel case is a great example of the difficulty that family law faces in adapting to the rapid and constant scientific evolution in the context of assisted reproduction, and in responding to the requests of transgender people. The complex decision adopted in the McConnel case establish that a man should be considered the mother of his child for the following reasons:

First, the term "mother", although it may have a legal meaning, has a mainly biological content, and is inseparably associated with the person with the capacity to become pregnant and give birth to their child.

Second, the possibility of changing people's gender does not require modifying the definition of the term "mother". Family law tries to allow people to freely develop their personality without being discriminated because of their sex, gender or sexual orientation; while the definition of who is a mother is a mere biological description of the role that people play in the reproductive process and not a legal one.

Third, the separation between gender and biology means that either a man or a woman can be mothers, since the relevant element is not the sex or gender of the person who become pregnant and give birth to their child, but rather their role in that process.

And four, the English solution takes into account the interests of third parties, and especially the right to know who is the person responsible for people's birth, as a part of the rights to identity and respect for private life; and, if they exist, the right of the partners of transgender or transsexual people to have their role legally recognized in this context.

Words are often symbols, and their meaning may not be unique. Traditionally, the term mother has been associated with woman and motherhood, just as the terms woman and man have been associated with a biological situation. The law has evolved allowing people to decide what their sex or gender is, according to their feelings and sexual identity; and later on to develop their personality without being discriminated against.

This regulation sometimes collides with other legal assets of special relevance, such as the legal security offered by civil registries in areas such as birth or filiation. Therefore, it seems necessary for the public authorities to have a margin of discretion, especially when the rights of minors are affected.

In summary, we are facing the latest response of family law to the demands and requests of the transgender community, and it implies that a term that has traditionally been linked exclusively to women, can now also be used by men, in the case of the female to male transgender who decide to become pregnant and give birth. Medical and technological advances indicate that in the future it will be feasible to transplant or modify reproductive organs, so that males can become pregnant and give birth, so this debate it may not be finished yet. 


\section{REFERENCES}

AGIUS, S., TOBLER, C., (2014) Trans and intersex people Discrimination on the grounds of sex, gender identity and gender expression, European Network of Legal Experts in the non-discrimination field, European Commission Directorate-General for Justice, Publications Office of the EU.

ALGHRANI, A., (2009) "The Human Fertilization and Embryology Act 2008: a missed opportunity?", Journal of medical ethics, Vol. 35, pp. 718-719. https://doi. org/10.1136/jme.2009.033365

APPELL, A., (2014) “Certifying Identity”, Capital University Law Review, Vol. 42, pp. 1-42.

BESSON, S., (2007) "Enforcing the child's right to know her origins: Contrasting approaches under the convention on the rights of the child and the European convention on human rights", International Journal of Law, Policy and the Family, Vol. 21 (2), pp. 137-159. https://doi.org/10.1093/lawfam/ebm003

CELADOR ANGÓN, O., (2020) "Transexualidad, libre desarrollo de la personalidad e interés del menor: análisis comparado de los modelos español e inglés", Revista general de derecho público comparado, $\mathrm{N}^{\circ} .27$.

CLARK, B., (2012) "A balancing act? the rights of donor-conceived children to know their biological origins", Georgia Journal of International and Comparative Law, Vol. 40, No 3, pp. 621-661.

COWAN, S., (2005) "Gender is no substitute for sex: a comparative human rights analysis of the legal regulation of sexual identity". Feminist Legal Studies, Vol. 13, pp. 67-96. https://doi.org/10.1007/s10691-005-1457-2

DAVIES, C., FERREIRA, N., MORRIS, A., MORRIS, D., (2016) “The Equality Act 2010: Five years on", International Journal of Discrimination and the Law, Vol.16, Issue: 2-3, pp. 61-65. https://doi.org/10.1177/1358229116655645

EUROPEAN COMMISSION (Directorate-General for Justice and Consumers) (2020), Legal gender recognition in the EU, The journeys of trans people towards full equality.

FALLETTI, E., (2014) "LGBTI discrimination and parent-child relationships: crossborder mobility of rainbow families in the European Union", Family Court Review, Vol. 52, Issue1, pp. 28-45. https://doi.org/10.1111/fcre.12068

FELL, V., DYBAN, M., (2017) “Equality Act 2010 (UK)”, The European Proceedings of Social \& Behavioral Sciences, Vol. 19: Lifelong Wellbeing in the World (WELLSO 2016), pp. 188-194. https://doi.org/10.15405/epsbs.2017.01.25

FISHBAYN, L., (2007) "Not Quite One Gender of the Other: Marriage Law and the Containment of Gender Trouble in the United Kingdom", American University Journal of Gender, Social Policy \& the Law, Vol. 15, No 3, pp. 413-441.

FOX, M., (2009) "The Human Fertilization and Embryology Act 2008: Tinkering at the Margins", Feminist Legal Studies, Vol. 17, pp. 333-344. https://doi.org/10.1007/ s10691-009-9129-2 
GONZALEZ-SALZBERG, D., (2014) "The Accepted Transsexual and the Absent Transgender: A Queer Reading of the Regulation of Sex/Gender by the European Court of Human Rights", American University International Law Review, Vol. 29, $\mathrm{N}^{\circ}$ 4, pp. $798-829$.

GRABHAM, E., (2010) "Governing Permanence: Trans Subjects, Time, and the Gender Recognition Act”, Social \& Legal Studies, Vol. 19, pp. 107-126. https://doi. org/10.1177/0964663909346200

HAND, J., (2012) "Unification, simplification, amplification? An analysis of aspects of the British Equality Act 2010", Commonwealth Law Bulletin, Vol. 38, Issue 3, pp. 509-528. https://doi.org/10.1080/03050718.2012.695001

HART, L., (2016) Relational Subjects: Family relations, law and gender in the European Court of Human Rights, Publications of the Faculty of Social Sciences, Unigrafia, Publications of the Faculty of Social Sciences, No 9, Helsinki.

KORKIAMÄKI, L. S., (2014) "Legal Gender Recognition and (Lack of) Equality in the European Court of Human Rights", The Equal Rights Review, Vol. 13, pp. 20-50.

LEIBETSEDER, D., GRIFFIN. G., (2018) "Queer and Trans Reproduction with Assisted Reproductive Technologies (ART)”, Europe, Vol. 20, Issue 1, pp. 1-9.

MARGARIA, A., FREEMAN, M., (2012) "Who and What is a Mother? Maternity, Responsibility and Liberty", Theoretical Inquiries in Law, Vol. 13, No. 1, pp. 153-178. https://doi.org/10.1515/1565-3404.1288

McCANDLESS, J. (2017), "Reforming birth registration law in England and Wales?", Reproductive Biomedicine \& Society Online, Vol. 4, pp. 52-58. https://doi. org/10.1016/j.rbms.2017.07.001

McCANDLESS, J., SHELDON, S., (2010) "The Human Fertilisation and Embryology Act (2008) and the Tenacity of the Sexual Family Form", Modern Law Review, Vol. 73, Issue 2, pp. 175-207. https://doi.org/10.1111/j.1468-2230.2010.00790.x

McCANDLESS, J., SHELDON, S. (2014), "Genetically challenged: the determination of legal parenthood in assisted reproduction", FREEMAN, T., GRAHAM, S., EBTEHAJ, F., RICHARDS, M. (Eds.), Relatedness in Assisted Reproduction: Families, Origins and Identities, Cambridge University Press, pp. 61-79. https:// doi.org/10.1017/CBO9781139814737.005

MINTER S., (2016) “Transgender Family Law”, Family Court Review, Vol. 56, pp 410-422. https://doi.org/10.1111/fcre.12357

MOYAL, D., SHELLEY, D., (2010) "Future child's rights in new reproductive technology: thinking outside the tube and maintaining the connections", Family Court Review, Vol. 48, No 3, pp. 431- 446. https://doi.org/10.1111/j.1744-1617.2010.01321.x

PERAL FERNÁNDEZ, L, (2000) "Concepto de sexo y discriminación por razón de sexo en el derecho social comunitario europeo: la contradictoria sentencia del Tribunal de Justicia de las Comunidades Europeas en el asunto Grant respecto de 
su jurisprudencia en el asunto P./S", Derechos y libertades: Revista del Instituto Bartolomé de las Casas, Año No 5, Nº 8, pp. 393-428.

POCKLINGTON, D., (2019) "Mother defined in common law", Law \& Religion UK, No 26.

SALAZAR BENÍTEZ, O., (2015) "La identidad de género como derecho emergente", Revista de estudios políticos, № 169, pp. 75-107. https://doi.org/10.18042/cepc/ rep.169.03

SANDLAND, R., (2005) "Feminism and the Gender Recognition Act 2004", Feminist Legal Studies, Vol. 13, pp. 43-66. https://doi.org/10.1007/s10691-005-1456-3

SANZ CABALLERO, S., (2003) "A propósito de sentencias de Goodwin e I o del debate sobre el matrimonio de transexuales ante TEDH", Revista española de derecho internacional, Vol. 55, $\mathrm{N}^{\mathrm{o}}$ 1, pp. 307-316.

SANZ CABALlERO, S., (2014) "El Tribunal Europeo De Derechos Humanos y su respuesta al reto de la transexualidad. Historia de un cambio de criterio", American University International Law Review, Vol. 29 No 4, pp. 831-868.

SHARPE, A., (2007) "A Critique of the Gender Recognition Act 2004", Journal of Bioethical Inquiry, Vol. 4, pp. 33-42. https://doi.org/10.1007/s11673-007-9032-y

TAITZ, J., (1986) "The Law Relating to the Consummation of Marriage where one of the Spouses is a Post-Operative Transsexual", Anglo-American Law Review, Vol. 15, pp. 141-148. https://doi.org/10.1177/147377958601500204

TURKMENDAG, I., (2012) “The donor-conceived child's 'right to personal identity': The public debate on donor anonymity in the United Kingdom", Journal of Law and Society, Vol. 39 (1), pp. 58-75. https://doi.org/10.1111/j.1467-6478.2012.00570.x

VIDAL GALLARDO, M., (2003) "El derecho a la identidad sexual como manifestación del derecho a la identidad personal", Laicidad y libertades: escritos jurídicos, $\mathrm{N}^{\circ}$. 3 , pp. 385-418.

WHITTLE, S., (2006) "The Opposite of Sex is Politics. The UK Gender Recognition Act and Why it is Not Perfect, Just Like You and Me", Journal of Gender Studies, Vol. 15, pp. 267-271. https://doi.org/10.1080/09589230600862166

WHITTLE, S., (2007) 'Sex Changes? Paradigm Shifts in 'Sex' and 'Gender' Following the Gender Recognition Act?”, Sociological Research Online, Vol. 12. Issue 1, pp. 75-89. https://doi.org/10.5153/sro.1511

ZIEGLER, R., (2020) "The European Union as a Protector and Promoter of Equality: Discrimination on Grounds of Sexual Orientation and Gender Identity", The European Union as Protector and Promoter of Equality (GIEGERICH, T., Ed.), Springer, pp. 283-296. https://doi.org/10.1007/978-3-030-43764-0_15

Received: February $1^{\text {st }} 2021$

Accepted: April 25 2021 